ningens rammer og viede sit liv til at vise menneskene, at "en almægtig Række af haandgribelige Mirakler er Verden, en Fontæne af Glæde, Ophav til din Tanke." - Her sagt med et lån fra Johs. V. Jensen.

Bogen er også en mageløst fortalt historie. Det er meget vanskeligt at finde mangler eller overflødige afsnit. Skulle der indvendes noget, må det blive et lille hjertesuk over, at Ole Jensen af hensyn til bogens omfang og form har valgt kun sporadisk at strejfe Løgstrups kunst- og sprogfilosofi. To områder, der kunne have været umådeligt spændende at få belyst af netop Ole Jensen, der i bogen demonstrerer sans for såvel kunst som sprog.

Historien om K. E. Logstrup kan med fordel og stort udbytte bruges som introduktion til Løgstrups forfatterskab, s som grundbog i studiekredse eller til al- i mindelig lystlæsning. Men selvom bogen kerc er tænkt og skrevet med også "den nye ken læser" i tankerne, er den på ingen måde en light-udgave af Løgstrups tænkning. Tværtimod. Den er et destilleret udtræk et af det væsentligste i Løgstrups tænk- Bec ning, fortalt og formidlet som en mage- $i$ løs historie.
PAW HEDEGAARD AMDISEN

\section{Their way?}

Quentin Skinner: Politik og historie, Hans

Reitzels Forlag, 2009, introduktion af

Frank Beck Lassen \& Mikeel Thorup, 275

sider, 299,-kr.

Det er glædeligt, at vi nu får adgang til nogle af den engelske idéhistoriker Quentin Skinners væsentligste artikler i en dansk version. Skinners tilgang til det idéhistoriske felt - både praktisk og metodologisk - er i de senere år kommet til at fylde mere og mere i idéhistoriske kredse rundt omkring i verden - herunder i Danmark. Og selvom vi hele tiden har haft adgang til Skinners tekster på et i særdeleshed formfuldendt engelsk, så er jeg sikker på, at den danske oversættelse vil give endnu flere idéhistorisk interesserede og kommende idéhistorikere herhjemme lejlighed til at stifte bekendtskab med Skinners uomgængelige overvejelser.

Men hvad er det, der gør Skinner til et uomgængeligt bekendtskab? Frank Beck Lassen og Mikkel Thorup peger deres fremragende og grundige introduktion til artikelsamlingen på en række faktorer, som det kunne værd at pege på i denne sammenhæng, og som også viser, at det forskningsprogram, Skinner har søsat for den idéhistoriske forskning, p.t. er et af de mest lovende. Kun tangeret af de forskningsprogrammer, der er blevet søsat i forlængelse af Michel Foucault og den begrebshistoriske 
tradition i Tyskland.

Først og fremmest markerer Skinner, sammen med Foucault og de tyske begrebshistorikere, et markant opgør med en klassisk måde at anskue idéhistoriefaget på - som studiet af de evige tids ideers vandring gennem historien. Vi kender på dansk grund betragtningen i fra Johannes Sløks programskrift Hvad s er idébistorie? (1968), hvor han lokaliserer tre basale ideer, der har været gennem- tue gående for hele den vestlige menneske- i heds historie. Internationalt repræsente- ' rede Arthur O. Lovejoy med sit fokus på "unit ideas" dybest set samme ahistoriske tilgang til det idéhistoriske felt.

I opposition til denne tilgang satte Skinner allerede i 1969 - med sin klassiske artikel "Meaning and Understanding sig in the History of Ideas", som også i en nyrevideret version fra 2002 er med i den danske udgivelse - fokus på tek- Skin ster (og ikke ideer) som idéhistorikerens egentlige genstandsfelt. I tilgift til denne den forståelseshorisont - den sprognyorientering fremhævede Skinner også, lige virkelighed, vi lever indenfor. At at en (idé)historisk tekst skulle ses i for- en sådan betragtning også har samtidshold til de (idé)historiske tekster - store diagnostisk og aktualiserende potentiale og små - som omgav denne tekst og burde være tydeligt. Den sproglige forikke i forhold til en lang kongerække af ståelseshorisont eller virkelighed, som vi tekster, som den historiske tekst efter- lever i, er resultatet af en kamp på ord følgende var blevet sat i "evig" dialog og argumenter, der kunne have haft et med. Dette betød for Skinner, at man helt andet udfald, end den fik, og den måtte se den enkelte tekst som en in- står til stadighed til at ændre, hvis vore tervenerende talehandling ytret $i$ en helt ord og argumenter er stærke og overbebestemt historisk og kulturel kontekst visende nok til at sætte en ny dagsorden. og ikke som en frit svævende entitet, Skinner var og er dog ikke kun en glimder forholdt sig til de samme eviggyl- rende metodolog. Han har også skrevet dige spørgsmål som historiske tekster en perlerække af spændende analyser 
af renæssancens og det tidlige moder- og Efterladte fortallinger er store dele af nes politiske tænkning. Med fokus på Kafkas forfatterskab blevet lettere tiltænkere som Machiavelli og Hobbes gængeligt for danske læsere. Værket, en har Skinner undersøgt og rekonstru- tiltrængt og flot udgivelse, fremstår som eret denne periodes politiske tænkning en ny standardudgave af Kafkas fortæli bredden og fundet nye og spændende linger på dansk - og er derfor et must forbindelseslinjer som mere traditionel for alle litteraturelskere, Kafka-fans og filosofi- og idéhistorisk litteratur på om- folk med hang til at samle på store klasrådet har overset. I denne sammenhæng sikere. Fortallinger rummer alle de tekster har den danske tekstsamling medtaget som Kafka selv offentliggjorde i sin en række eksemplariske artikler. levetid; Efterladte fortallinger indeholder

Tekstsamlingen er vel oversat, har alle større fortællinger og fragmenter som sagt en fremragende indføring af (parabler, aforismer, dagbogsoptegnelFrank Beck Lassen og Mikkel Thorup ser og selvbiografiske skitser) fra hans og der er på denne baggrund absolut efterladte papirer. Redaktionelt har man ingen undskyldninger for ikke at stifte valgt at lade Villy Sørensens og Per Øhrbekendtskab med Skinners tilgang til gaards gamle oversættelser fra Dommen den idéhistoriske metier. Bogen bør og andre fortallinger fra 1967 indgå i revivære pligtlæsning for alle med interesse deret form i denne udgave. Fornuftigt for det idéhistoriske felt, og for manges nok; de udgør i sig selv et lille sprogligt vedkommende er jeg sikker på, at pligt- og litterært mesterværk.

læsningen vil forvandle sig til lystlæs- De resterende fortællinger, som ning, så snart de får øjnene op for det udgør langt størstedelen af materialet, store idéhistoriske anvendelsespoten- er oversat af Isak Winkel Holm. Jeg tiale, der findes i Skinners rekonstruk- synes godt om denne oversættelse. Det tion af fortidige teksters betydning i siger næsten sig selv, at det er alt andet samspil med deres sproglige kontekst. end nemt at oversætte Kafkas på mange måder ellers meget stringente og klare, men alligevel fuldstændig surrealistiske prosa. Det er nærliggende enten at forfalde til ironisk distance eller til en

RIKKE LOUISE PETERS

\section{Kafka på dansk}

Franz Kafka: Fortallinger 1 \& 2, Gyldendal, 2008, $267+419$ sider, 450,-kr.

Med Gyldendals nye store Kafka-sats- stil. Stilen er gammeldags uden at virke ning bestående af to bind: Fortallinger bedaget. 